\title{
Environmental Issue of Coal Ash Imported From Japan after Fukushima Nuclear Power Plant Disaster: A Case Review in South Korea
}

\author{
Namil Um*, Yoon Soo Park and TaeWan Jeon \\ Environmental Resources Research, National Institute of Environmental Research, Republic of Korea
}

*Corresponding author: Namil Um, Environmental Resources Research, National Institute of Environmental Research, Republic of Korea

\begin{tabular}{|c|c|}
\hline ARTICLE INFO & ABSTRACT \\
\hline $\begin{array}{l}\text { Received: 慧 September 30, } 2020 \\
\text { Published: 慧 October 08, } 2020\end{array}$ & \multirow{2}{*}{$\begin{array}{l}\text { In South Korea, the cement companies are importing Coal Ash (CA) from Japan and } \\
\text { recycling it as an alternative raw material for cement and an auxiliary fuel for the furnace } \\
\text { in the cement manufacturing process. However, the issue of human and environmental } \\
\text { risks has been raised because of the radioactive contamination that occurred from } \\
\text { the tsunami in Japan in } 2011 \text {. Therefore, in this review, the environmental issue of CA } \\
\text { imported from Japan after the Fukushima Nuclear Power Plant Disaster (FNPPD) and the } \\
\text { national countermeasures for solving it were discussed. }\end{array}$} \\
\hline $\begin{array}{l}\text { Citation: Namil Um, Yoon Soo Park, } \\
\text { TaeWan Jeon. Environmental Issue of } \\
\text { Coal Ash Imported From Japan after }\end{array}$ & \\
\hline $\begin{array}{l}\text { Fukushima Nuclear Power Plant Disaster: } \\
\text { A Case Review in South Korea. Biomed }\end{array}$ & $\begin{array}{l}\text { Keywords: Coal Ash;Transboundary Movement of Waste;Environmental Issue; } \\
\text { Fukushima Disaster }\end{array}$ \\
\hline MS.ID.005037. & $\begin{array}{l}\text { Abbreviations: TMW: Transboundary Movement of Waste; BC: Basel Convention; CA: } \\
\text { Coal Ash; CPP: Coal-Fired Power Plant }\end{array}$ \\
\hline
\end{tabular}

\section{Introduction}

Since many countries were reluctant to dispose of waste with hazardous substances in their territories to protect their own country, they relied on exporting the waste to underdeveloped or developing countries in an easy way to solve this problem. However, this Transboundary Movement of Waste (TMW) caused environmental pollution in importing countries, and the necessity for international cooperation to protect the environments of underdeveloped or developing countries was recognized as a national issue [1]. As such, the Basel Convention (BC) on the control of TMW and their disposal was adopted in March 1983 and came into force in May 1992 to protect the environment from illegal TMW and support eco-friendly projects [2,3]. South Korea joined the BC in February 1994 and the TMW is controlled by the 'Transboundary Movement of Waste and Their Disposal Act' and related enforcement ordinance, which were released from the Ministry of Environment [4,5]. In this situation, the amount-scale of various wastes imported to South Korea has increased every year. Among them, the Coal Ash (CA) accounts for the largest proportion and it corresponded to over $70 \%$ of all the imported waste. The import of CA has gradually increased since 2008 and all of it comes from Japan. The imported CA is mostly used as subsidiary fuels or alternative raw material of cement for building construction [6]. However, the issue of human and environmental risks has been raised by both the National Assembly and private organizations. Because the cement produced by using the CA imported from Japan, where the radioactive contamination occurred from the tsunami, has uncertainty about safety.

\section{Mini Review}

CA is the inorganic waste that remains unburned in the furnace of Coal-Fired Power Plant (CPP). It is classified into two main types with fly ash (collected from electrostatic precipitators) and bottom ash (collected from the bottom of boiler units). The particle sizes are widely distributed between under $0.1 \mathrm{um}$ and over $5 \mathrm{~cm}$ in diameter. The main components are silica dioxide (SiO2), aluminum oxide (Al203), iron oxide (Fe203), calcium oxide ( $\mathrm{CaO}$ ), and magnesium oxide $(\mathrm{MgO})[7,8]$. CA has been utilized as a recyclable material in the 
industrial field and can play an important role as a new alternative resource. Indeed, many research studies were investigated, such as the utilization of cementitious resource and concrete aggregate $[9,10]$, the investigation of physical characteristics for recycling material [11], the reuse of shotcrete and building materials $[12,13]$, the application of nanoporous materials in the synthesis field [14], etc. For this reason, CA is one of the large-scale wastes that are traded internationally. Based on the BC, B2050 code (included in List B of BC text) applies to CA as a general-management waste which doesn't contain on hazardous substance [15]. In the case of South Korea, according to Korea Environment Corporation [6], the total amount of CA on transboundary movement was about 1.3 Million Tons (MT) in 2016. The import scale of CA increased more than three times in 8 years from about 0.4 MT in 2008, when CA began to be imported [16].

In South Korea, CA is indicated as a recyclable by-product in the 'Act on the Promotion of Saving and Recycling of Resources' released from the Ministry of Environment [17]. Besides, the specific recycling methods of CA are provided by the 'Guideline for Recycling of Steel Slag and Coal Ash Producers (Notification No. 2016-217, Ministry of Environment)' [18]. Thus, the major cement companies import the $\mathrm{CA}$ and recycle it as an alternative raw material for cement and an auxiliary fuel for the furnace in the cement manufacturing process; in 2016, 1.2 MT of imported CA was recycled as alternative material and 0.1 MT was an auxiliary fuel [6]. All imported CA comes from a Japanese CPP. In Japan, the large amount of CA has generated annually from the CPP and it was approximately 7.1 MT in 2000 [19]. Among them, more than 1.5 MT of CA was sent to landfill sites [20]. Landfill treatment in Japan is burdensome for CPP because it requires a lot of costs. Therefore, they choose to export to Korea, which costs less than landfill treatment. From the perspective of the importer (cement companies in South Korea), it is an attractive deal that cannot be rejected. Because importer can receive the treatment cost from Japanese CPP and generate the profits through domestic recycling.

Fukushima Nuclear Power Plant Disaster (FNPPD) was occurred by the Tohoku earthquake and tsunami in March 2011 [21]. The earthquake had generated a tsunami with $14 \mathrm{~m}$ high. Consequently, the tsunami swept over the plant's seawall and then hit the lower parts of the nuclear power plant reactors [22,23]. The resultant loss of reactors led to the release of radioactive contamination [24,25]. Large amounts of water contaminated with radioactive isotopes were released into the Pacific Ocean during and after the disaster $[26,27]$. According to a 2014 report by the United Nations Scientific Committee on the Effects of Atomic Radiation (UNSCEAR) [28], there has been ongoing controversy over the health effects of the disaster. Besides, an ongoing intensive cleanup program to both decontaminate affected areas and decommission the nuclear power plant will take several decades [29,30].
After FNPPD, trace amounts of radioactivity, including iodine-131 (I-131), cesium-134 (Ce-134), and cesium-137 (Ce137), were widely observed [31-34]. As the result, it was confirmed that the radioactive material constantly can be released from the containment vessels in the nuclear power plant for several reasons: deliberate venting to reduce gas pressure, deliberate discharge of coolant water into the sea, and uncontrolled events. Indeed, in 2015 (4 years after FNPPD), the tap water contamination was still higher in Tokyo compared to other cities in Japan [31]. Thus, concerns about the possibility of a large scale release led to a 20 kilometer exclusion zone around the power plant and recommendations that people within the surrounding 20-30 kilometer zone stay indoors. All CA imported to South Korea comes from CPP located in 15 regions including Hekinan, Hokuriku, Isogo, Kobe, Maijuru, Matsushima, Matsuura, Miike, Nanao, Noshiro, Sakata, Tachibana, Takehara, Tomakomai, and Tsuruga in Japan [6]. Looking at the distance between the local points of FNPPD and CPP, the nearest region was Tachibana (within $30 \mathrm{~km}$ ), followed Matsushima (within $100 \mathrm{~km}$ ), Matsuura (within $100 \mathrm{~km}$ ), Hokuriku (within $200 \mathrm{~km}$ ), Isogo (within $250 \mathrm{~km}$ ), and Isogo $(250 \mathrm{~km})$. All areas mentioned above have potential exposure to the radioactive material. In particular, the CA generated from the CPP in Tachibana, which is a region located in Fukushima, has the potential danger directly affected by the radioactive contamination.

Most Korean has a negative impression of the CA imported from Japan because of FNPPD. In particular, the National Assembly, the environmental civic group, and the media have raised concerns about the deterioration of the environment around the cement companies (which import the CA) and the impact on the human body of residents living in the apartment built of cement produced by using imported CA. Thus, some research institutes with national support investigated the health impact of residents living around in the regions of Jecheon, Danyang, Samcheok, Gangneung, Donghae, and Jangseong where cement companies are concentrated $[35,36]$. As a result, only a few patients with pneumoconiosis and chronic obstructive pulmonary disease were found, but there were no cases of radiation damage. Additionally, the government tightened its safety inspection with radioactivity tests for CA imported from Japan, in an apparent attempt to counter the FNPPD.

The Wonju Local Environment Agency is in charge of the inspection institution. This agency is performing the radiation test $(\mathrm{uSv} / \mathrm{h})$ and radioactivity tests including $\mathrm{I}-131$ (Bq/kg), Ce$134(\mathrm{~Bq} / \mathrm{kg})$, and Ce-137 (Bq/kg) of the CA imported from Japan. According to the analysis data for three years (2016-2018) [37], the result of radiation was detected within the range from 0.143 $\mathrm{uSv} / \mathrm{h}$ to $0.233 \mathrm{uSv} / \mathrm{h}$, and it indicates that the data was also within the range of Environmental Radiation Dose Rate (0.05-0.3 uSv/h). In the case of radioactivity, the Ce-134 and Ce-137 were detected within the ranges from $0.180 \mathrm{uSv} / \mathrm{h}$ to $0.557 \mathrm{uSv} / \mathrm{h}$ and from 0.216 
$\mathrm{uSv} / \mathrm{h}$ to $0.584 \mathrm{uSv} / \mathrm{h}$, respectively. Both results did not exceed the value of the standard of Radioactivity in Food (100 Bq/kg; the sum of Ce-134 and Ce-137). Whereas, I-131 was detected within the range from $0.211 \mathrm{~Bq} / \mathrm{kg}$ to $0.563 \mathrm{~Bq} / \mathrm{kg}$ and did not exceed the Radioactivity in Food (100 Bq/kg; only I-131).

To confirm the harmfulness of cement produced by using the imported CA, the National Institute of Environmental Research conducted an environmental assessment of it [38]. The heavy metal contents with $\mathrm{Pb}, \mathrm{Cu}, \mathrm{As}, \mathrm{Hg}$, $\mathrm{Cd}$, and $\mathrm{Cr} 6$ + were considered to be the assessment elements for determining harmfulness. In South Korea, there is no legal standard for the safety of cement with waste. In general, the government requires the contents of six heavy metals for permitting recyclable waste. Their contents can be obtained using the Korean standard official methods of $\mathrm{Pb}$ (ES 06402.2), $\mathrm{Cu}$ (ES 06401.2), As (ES 06403.2a), Hg (ES 06404.1a), Cd (ES 06405.2), and Cr6+ (ES 06407.2) [39]. According to the analysis result for last three years, the concentrations of $\mathrm{Pb}, \mathrm{Cu}, \mathrm{As}, \mathrm{Hg}, \mathrm{Cd}$, and $\mathrm{Cr} 6+$ were $88.38-147.90 \mathrm{mg} / \mathrm{kg}, 33.06-210.96 \mathrm{mg} / \mathrm{kg}, 8.90-18.34 \mathrm{mg} / \mathrm{kg}, 0.04$ $0.17 \mathrm{mg} / \mathrm{kg}, 8.40-8.91 \mathrm{mg} / \mathrm{kg}$, and 6.11-11.15 mg/kg, respectively. Compared to the six element's contents of a typical cement product, there was little difference.

In South Korea, the waste is managed as two types of general waste and hazardous waste. When imported waste is classified as hazardous waste, its import is strictly regulated by the government. Here, the leaching toxicity with $\mathrm{Pb}$ (standard value of $3 \mathrm{mg} / \mathrm{L}$ ), $\mathrm{Cu}$ (3 mg/L), As (1.5 mg/L), Hg (0.005 mg/L), Cd (0.3 mg/L), and Cr6+ $(1.5 \mathrm{mg} / \mathrm{L})$ is considered to be the standard for determining hazardous wastes [39]. The leaching toxicity test is carried out using the Korean standard official method of a sample of preparation (ES 06150) [40]. According to the results analyzed from the National Institute of Environmental Research [41], the leaching toxicity of CA imported from Japan did not exceed the standards. The values of $\mathrm{Pb}, \mathrm{Cu}, \mathrm{Hg}$, and $\mathrm{Cd}$ were not detected, whereas As and Cr6+ showed the low leaching concentrations of $0.01-0.03 \mathrm{mg} / \mathrm{L}$ and 0.02-0.15 mg/L, compared with the standard of $1.5 \mathrm{mg} / \mathrm{L} . \mathrm{In} 2017$, the amount of domestic CA generated from the Korean CPP was up to $8 \mathrm{MT}$, of which $20 \%$ (1.6 MT) depends on landfill treatment [41]. Despite the high dependence on the landfill for domestic CA, the cement companies could not stop importing the CA from Japan due to the economic benefits. Therefore, two issues with the potential danger of radioactive contamination and the stagnant recycling situation of domestic CA can be major hurdles in achieving effective management policy on TMW in South Korea. To address the two issues, several countermeasures must be considered as follow. First, the current standard of the imported CA needs to be strengthened and to be strictly controlled like a regulated or prohibited waste, in only countries where a radioactive accident has occurred (even if the level of radioactivity in the CA does not exceed the related standard) [42].
Second, the improved government-initiated support system (e.g., exemption of road toll, support of financial loan, stabilization of recycling market, expansion of demand-route for a recycled product, etc.) can be required to promote the recycling of domestic CA [43]. Third, the producer's responsibility for recycling needs to be strengthened [44]. Namely, the recycling cost of CA can be shared by the CPP (producer) by estimating the recycling fulfillment rate. Fourth, the list of recyclable items from the use of CA, which can be approved by the government without any permission procedure, should be expanded: the existing 15 items including concrete admixture, cement, lightweight aggregate, cement secondary product, embankment, cover, road aggregate, wood adhesive, cement clinker, drainage layer, ceramic, rubber and plastic filler, paint/abrasive/insulation materials, steelmaking, and topsoil fertilizer [18]. Fifth, it is necessary to continuously discuss additional measures to reduce the import amount and increase the domestic recycling ratio by operating a public-private consultative group including the government, CPP, and cement company (importer). This review covers only the issue of CA imported from Japan after FNPPD in South Korea. Since the environmental issue on the TMW varies depending on different situations in each country, there are limits to the direct application of this case review. However, it can suggest a good reference for understanding the sensitive matter on the TMW and finding the national countermeasures to solve it in each country.

\section{Acknowledgment}

This work was supported by a grant from the National Institute of Environmental Research (NIER), funded by the Ministry of Environment (MOE) of the Republic of Korea (NIER-2018-01-01040).

\section{References}

1. Alter H (1997) Industrial recycling and the Basel Convention. Resources Conservation and Recycling 19(1): 29-53.

2. (1992) Basel Convention, Parties to the Basel Convention.

3. (1992) Convention, Overview. Basal Convention.

4. (2020) Ministry of Environment, List of Waste Subject to the Transboundary Movement of Waste and Their Disposal Act: Ministry of Environment Notification No. 2020-141.

5. (2020) Ministry of Environment, Transboundary Movement of Waste and Their Disposal Act.

6. (2020) Korea Environment Corporation, Allbaro system: Export \& import waste portal system.

7. Liang W, Wang GW, Ning XJ, Zhang JL, Li YJ (2020) Effect of CaO mineral change on coal ash melting characteristics. Journal of the Energy Institute 93: 642-648.

8. Qin Q, Zhou J, Lin B, Xie C, Zhou L (2020) Influence of coal ash on the characteristics of corn straw pyrolysis products. Bioresource Technology 318: 124055 .

9. Mangi SA, Ibrahim MHW, Jamaluddin N, Arshad MF, Mudjanarko SW (2019) Recycling of coal ash in concrete as a partial cementitious resource. Resources 8(2): 99. 
10. Navdeep S, Mithulraj M, Shubham A (2019) Utilization of coal bottom ash in recycled concrete aggregates based self-compacting concrete blended with metakaolin. Resources, Conservation and Recycling 144: 240-251.

11. Rifal A, Yasufuku N, Omine K, Tsuji K (2009) Utilization of coal ash as recycling material options in view point of geoenvironment. Advances in Environmental Geotechnics: Springer 715-720.

12. Anghelescu L, Cruceru M, Diaconu B (2019) Building materials obtained by recycling coal ash and waste drilling fluid and characterization of engineering properties by means of artificial neural networks. Construction and Building Materials 227: 116616.

13. Kim H, Yang JF, Sekino T, Lee SW (2009) Practical recycling application of power plant coal ash for high performance shotcrete material. Materials Science Forum 620: 251-254.

14. Lee YR, Soe JT, Zhang S, Ahn JW, Park MB, et al. (2017) Synthesis of nanoporous materials via recycling coal fly ash and other solid wastes: A mini review. Chemical Engineering Journal 317: 821-843.

15. (2014) Basel Convention, Basel Convention on the Control of Transboundary Movements of Hazardous Wastes and Their Disposal.

16. (2016) Ministry of Environment, Environmental Statistics Yearbook.

17. (2020) Ministry of Environment, Act on the Promotion of Saving and Recycling of Resources.

18. (2016) Ministry of Environment Guideline for Recycling of Steel Slag and Coal Ash Producers: ministry of Environment Notification No 2016-217.

19. Rifai A, Yasufuku N, Tsuji K (2009) Characterization and effective utilization of coal as soil stabilization on road construction. Ground Improve Technol Case Histor Geotech Soc Singapore (GeoSS): 469-474.

20. Kunitomo H (2009) Recycling of coal ash: current activities and challenges for the future. In: Proceedings of symposium on effective use of coal ash: 23

21. Lipscy PY, Kushida KE, Incerti T (2013) The Fukushima disaster and Japan's nuclear plant vulnerability in comparative perspective. Environmental Science \& Technology 47(12): 6082-6088.

22. Clarke RA, Eddy RP (2017) Warnings: Finding Cassandras to stop catastrophe. Harper Collins, US.

23. Martin F (2011) Report Finds Japan Underestimated Tsunami Danger The New York Times.

24. Fackler M, Wald ML (2011) Life in Limbo for Japanese Near Damaged Nuclear Plant. The New York Times.

25. (2020) Reconstruction Agency, Great East Japan Earthquake.

26. Fackler M (2016) Japan $\$ 320$ Million Gamble at Fukushima: an Underground Ice Wall. The New York Times.

\section{ISSN: 2574-1241}

DOI: 10.26717/BJSTR.2020.31.005037

Namil Um. Biomed J Sci \& Tech Res

This work is licensed under Creative

Commons Attribution 4.0 License

Submission Link: https://biomedres.us/submit-manuscript.php
27. Fackler M, Tabuchi H (2013) With a Plant's Tainted Water Still Flowing, No End to Environmental Fears. The New York Times.

28. (2014) United Nations Information Service, Increase in Cancer Unlikely following Fukushima Exposure-says UN Report.

29. (2019) Fukushima disaster: Japan acknowledges first radiation death from nuclear plant hit by tsunami. ABC News.

30. Mccurry J (2014) Fukushima operator may have to dump contaminated water into Pacific. The Guardian.

31. Foust NL (2015) Stealthy, silent destroyer of DNA. The Australian.

32. Kim S, Min BI, Park K, Yang BM, Kim J, et al. (2019) Estimation of longterm effective doses for residents in the regions of Japan following Fukushima accident. Nuclear Engineering and Technology 51: 837-842.

33. Mackenzie D (2011) Fukushima radioactive fallout nears Chernobyl levels. NewScientist.

34. Winter M (2011) Report: Emissions from Japan plant approach Chernobyl levels.

35. Choi MS (2015) Damage in pulmonary function of residents near a cement factory and limestone. Korea University.

36. Park CH, Ahn SC, Kim H, You SD (2016) A health survey on residents living mear cement plant: The achievements and limitations. Journal of Environmental Health Sciences 1: 65.

37. (2020) Wonju Local Environment Agency, Analysis of Coal Ash Imported from Japan.

38. (2020) National Institute of Environmental Research, The monitoring result of heavy metal contents in cement produced by using coal ash imported from Japan as a raw material.

39. (2011) Ministry of Environment, Korean Standard Methods.

40. (2018) Ministry of Environment, Enforcement Regulation of Wastes Control Act

41. Um N, Park YS, Kim YJ, Kim WI, Park SO, et al. (2018) Study on the performance improvement of domestic management system for effective control of transboundary movements of waste. National Institute of Environmental Research.

42. Ock HJ (2019) Seoul to toughen inspections of waste imports from Japan. The Korea Herald.

43. (2017) UNDP, Sustainable Development Goals (Policy Brief Series): Examples of Korea's successful policies in waste management \& lessons learned that could apply in other countries.

44. Kim KY (2010) Extended Producer Responsibility (EPR). Korea Environmental Policy Bulletin 8(1)

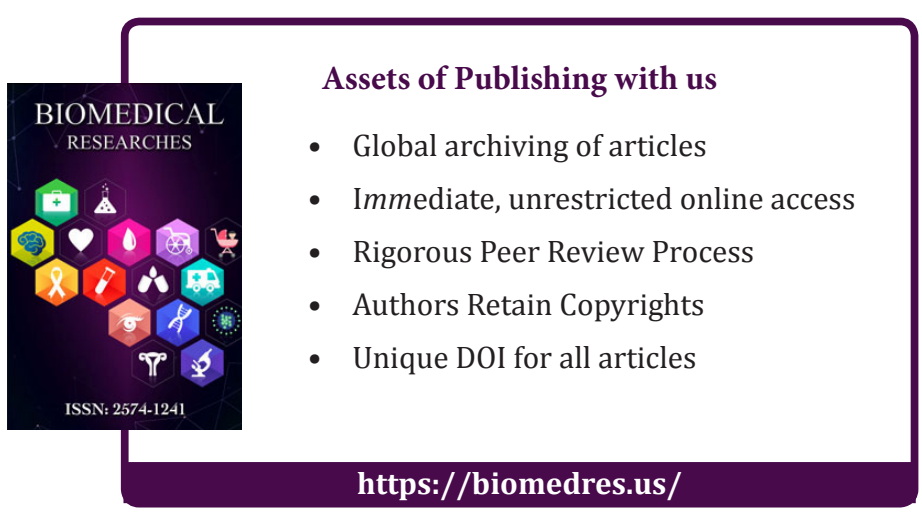

